シリコーン油入変圧器の超音波油中ガス分析

$$
\begin{array}{llll}
\text { 正員林 喬 久 } & \text { (千葉工大) } \\
\text { 正 員 加覧 俊 平 (千葉工大) }
\end{array}
$$

\title{
Gas Analysis Test on Silicone Liquid Transformer by Utilizing Ultrasonic Wave Irradiation
}

Takahisa Hayashi, Member, Shumpei Garan, Member (Chiba Institute of Technology)

$$
\text { キーワード：シリコーン油, 変圧器, 超音波, ガス分析 }
$$

変圧器内部の異常現象を検知する手段の一つとして 油中がス分析が広く用いられている。この方法は, 変 圧器内部に局部加熱や放電などの異常が発生すると, 絶縁油と油浸絶縁物が分解し, $\mathrm{H}_{2}, \mathrm{CO}$, 炭化水素な どのガスを生成するので，これらの油中溶解ガスを測 定して翼常を判定する。

油中からガスを抽出する装置としては，種々のもの が考案され実用化されている(1)。原理的に多くは絶緑 油を隇圧状態にするとき油中と油面空間に生ずる圧力 差を利用するものである。そして水銀によるトリチェ リ真空を利用する方法, テプラーポンプに水銀拡散ポ ンプを併用する方法，真空ポンプと移動弁を用いる方 法，ピストンを用いる方法などが用いられている。こ のほかに，不活性ガスを絶縁油中に吹き込んで油面上 にガスを追い出す方法（stripping method）がある。 これらの装置は大形で操作が繁雑であり，またガス抽 出に長時間を要する。

著者らは, シリコーン油入変圧器を対象にして, 鉄 道工場などの日常試験において操作が簡便で短時間に 油中ガスを分析できる方法を考案，検討した。その方 法法，試料油に超音波を照射するとき生ずるキャビテ ーション (空洞現象)により油中溶解ガスを気泡化 し，採取したガスをガスクロマトグラフィで分析する ものである。

実験に用いた超音波発生器は，発振周波数は 28 $\mathrm{kHz}$, 主発振電力增幅方式により $200 \mathrm{~W}$ の高周波電 力を発生する。これを超音波伝達ケースに付けたフェ ライト振動子により超音波に変換し，水を媒体として シリンジ中の試料油に照射する。

陚料油に超音波を照射する状況を図 1 に示す。がラ ス製シリンジに $50 \mathrm{~m} l$ の試料油を密封して, 後述の

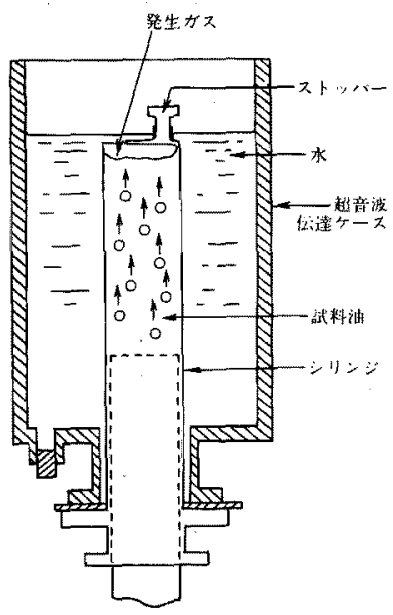

図 1 超音波照射状況

Fig. 1. Condition of ultrasonic wave irradiation.

前処理を施す。そしてシリンジを超音波伝達ケースに 装着する。次いで超音波を試料油に伝達するために， 水をシリンジ上端を超えるところまで入れる。超音波 を発生させると, 気泡化したガスがシリンジ上部に滞 留する。所定の時間経過後, 超音波の発生を停止し, シリコンゴム製のストッパを通して発生ガスを, 1 $\mathrm{m} l$ の気密シリンジに採取する。

新幹線などの交流車両変圧器に使用されている絶縁 油は, $50 \mathrm{CS}\left(25^{\circ} \mathrm{C}\right)$ の動粘度をもつジメチルシリコ ーン油(2)である。これを脱気濾過して，100 $\mathrm{ml}$ の油 中に $\mathrm{O}_{2}$ 溶解量を $0.5 \sim 1.5 \mathrm{ml}, \mathrm{N}_{2}$ 溶解量を $1.0 \sim$ $3.0 \mathrm{~m} l$ 程度にした油を変圧器に封入し, 金属べロー ズを用いた無圧密封方式で用いられる。このような脱 


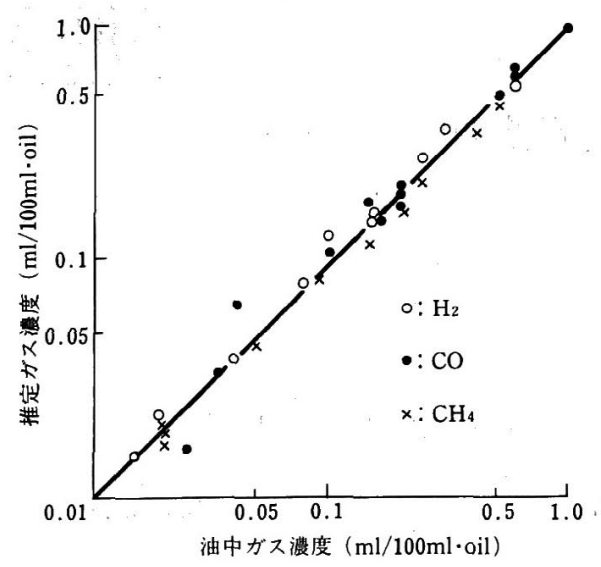

図 2 油中ガス濃度と推定ガス濃度

Fig. 2. Gas concentration in oil vs. presumed gas concentration.

気シリコーン油では空洞現象を発生しにくいことを確 認した。そこで気泡発生を助長することを検討した結 果, 試料油に空気の注入が手軽で適当であることが明 らかにされた。

キャビテーションしきい值は, 気体の含有量により 決定される。すなわち, 気体の飽和度の大きいほど, 空洞現象は起こりやすい。超音波を照射すると, 液体 中に溶解しているガス成分がキャビテーション気泡内 に入り込み, 脱気が行われる。また気泡どうしが互い に引きつけあって大きな気泡となり浮上する。油中ガ ス抽出の前処理法として, 実験結果より, シリンジに 封じた試料油に $7.5(\mathrm{~m} l / 100 \mathrm{~m} l \cdot \mathrm{oil})$ の空気を注入し 24 時間放置, 未溶解の空気を放出後に超音波を 1 分 間照射することに決めた。

シリコーン油入変圧器に異常を生じている場合, 顕 著に発生するガスは, $\mathrm{H}_{2}, \mathrm{CH}_{4}, \mathrm{CO}$ であることが見い だされている( ${ }^{(3)(4)}$ 。従って, これら限定されたガスを 検知しても, 変圧器異常の有無は判定できると考元ら れる。脱気シリコーン油に, $0.05,0.10,0.25$, $0.50,1.00(\mathrm{~m} l / 100 \mathrm{~m} l \cdot$ oil $)$ の濃度 の $\mathrm{H}_{2}, \mathrm{CH}_{4}, \mathrm{CO}$ を溶入した試料油を作製し，それぞれについて前記の 超音波油中ガス分析の測定を 10 回ずつ行った。その 結果から, 抽出ガス量を $x(\mathrm{~m} l)$, 油中溶解ガス濃度 を $y(\mathrm{~m} l / 100 \mathrm{~m} l \cdot \mathrm{oil})$ とするとき, 両者の間に次の 関係が得られた。

$$
\begin{aligned}
& \mathrm{H}_{2}: y=17.1688 x-0.02578 \\
& \mathrm{CH}_{4}: y=56.4233 x+0.0030 \\
& \mathrm{CO}: y=22.2222 x-0.1222
\end{aligned}
$$

この検量式から, 母油である変圧器油中に存在してい る被検成分ガスの濃度を推定することができる。

この超音波油中ガス分析の測定精度について検討し た。脱気シリコーン油に分析用標準ガス（純度 99.99\%）を注入し，前記の方法に従って油中ガス分 析を行った。検量式から試料油中の $\mathrm{H}_{2}, \mathrm{CH}_{4}, \mathrm{CO}$ の 濃度を推定し，作製濃度と比較した結果を図 2 に示 す。いずれのガスも試料油中の濃度が $0.05(\mathrm{ml} / 100$ $\mathrm{m} l \cdot$ oil $)$ を超えると, 両者はよく一致する。

超音波による空洞現象を利用した油中溶解ガス抽出 法を考案し，これを用いてシリコーン油入変圧器の内 部異常を簡便に検知できることを明らかにした。ま た, この方法での鉱油などを用いた電力用変圧器への 適用も考えられ，検討中である。

終りに，実験に協力された元鉄道技研雨倉孝之主 任研究員に謝意を表す。（平成 2 年 2 月 19 日受付)

\section{文 献}

（1）伊勢：「油中ガス分析について」, 石油学誌，17，564(昭49 -7)

（2）加臨：「車両変圧器に使用するシリコーシ油」, 同上, 17 , 580 (昭 49-7)

（3）桑原・鶴田・石井・吉永：「シリコーン油中の放電に上るガ スの発生」, 電気論 A, 97, 267 (昭 52-5)

(4) 雨倉：「油中ガス分析による䉓車変圧器の管理」, 鉄道技研 速報，80，148(昭 55-11)

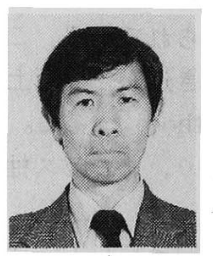

\section{林喬 久 (正員)}

昭和 20 年 2 月 18 日生。 42 年 3 月千葉工業大学電気工学科卒業。 44 年 4 月同大学電気工学科助手, 現在 に至る。主として，液体誘電体の高 電圧絶緑の研究に従事。静電気学会, 放電研究グルー プ会員。

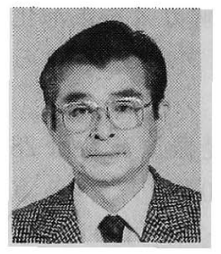

\section{加 覧 俊 平 (正員)}

大正 13 年 3 月 15 日生。昭和 24 年 3 月東京工業大学電気工学科卒 業。同年 11 月日本国有鉄道本社採 用。 48 年 4 月鉄道技術研究所電力 応用研究室長, 51 年 4 月千葉工業大学電気工学科教 授, 現在に至る。工学博士。高電圧絶緑の研究と教育 に従事。 